\title{
Cancer patients, emergencies service and provision of palliative care
}

Bruno Miranda ${ }^{1}$, Suely Arruda Vidal ${ }^{2 *}$, Maria Júlia Gonçalves de Mello ${ }^{3}$, Jurema Telles de Oliveira Lima ${ }^{4}$, Judith Correia RêGo ${ }^{5}$, Milena Cândido Pantaleão ${ }^{5}$, Viviane Gomes Carneiro Leão ${ }^{5}$, Fernando Antônio Ribeiro de Gusmão Filho ${ }^{6}$, José Iran da Costa Júnior ${ }^{7}$

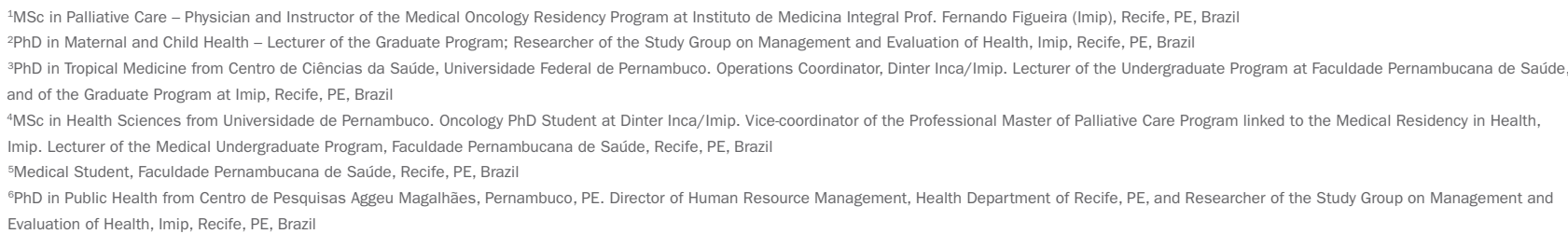

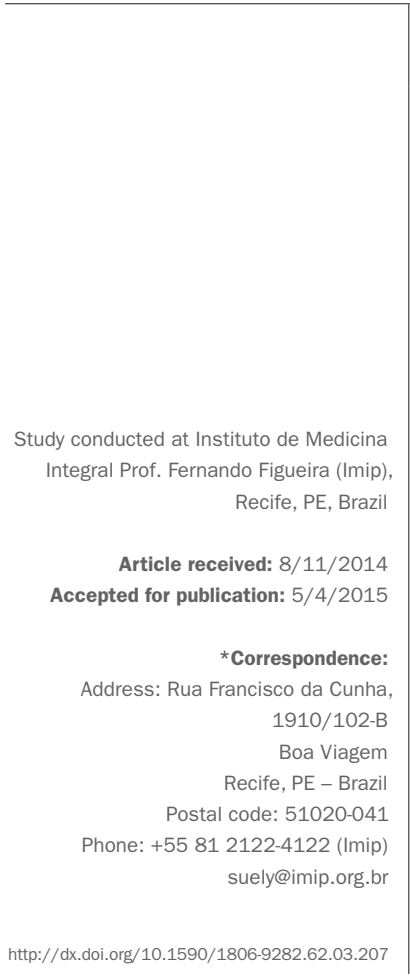

\section{SUMmARY}

Objective: To describe the clinical and sociodemographic profile of cancer patients admitted to the Emergency Center for High Complexity Oncologic Assistance, observing the coverage of palliative and home care.

Method: Cross sectional study including adult cancer patients admitted to the emergency service (September-December/2011) with a minimum length of hospital stay of two hours. Student's t-test and Pearson chi-square test were used to compare the means.

Results: 191 patients were enrolled, 47.6\% elderly, 64.4\% women, $75.4 \%$ from the city of Recife and greater area. The symptom prevalent at admission was pain (46.6\%). $4.2 \%$ of patients were linked to palliative care and $2.1 \%$ to home care. The most prevalent cancers: cervix $(18.3 \%)$, breast $(13.6 \%)$ and prostate $(10.5 \%)$; $70.7 \%$ were in advanced stages (IV, $47.1 \%$ ); $39.4 \%$ without any cancer therapy. Conclusion: Patients sought the emergency service on account of pain, probably due to the incipient coverage of palliative and home care. These actions should be included to oncologic therapy as soon as possible to minimize the suffering of the patient/family and integrate the skills of oncologists and emergency professionals.

Keywords: neoplasms, palliative care, home care, emergency medical services.

\section{INTRODUCTION}

Cancer is currently the second cause of death in the world ${ }^{1}$ and in Brazil, ${ }^{2}$ causing greater impact in poor and developing countries. ${ }^{3}$ This fact is associated with the increasing aging of the world population; the adoption of unhealthy habits such as smoking, sedentary lifestyle and poor diet; sexually transmitted infections; and lack of access to health services for early detection and treatment. ${ }^{4}$

In Brazil, factors such as changes in the demographic profile with more people aged 50 years or older and an epidemiological polarization caused by growth in chronicdegenerative diseases, increase the likelihood of cancer. ${ }^{2}$

This change in the Brazilian profile led to the need for restructuring the health system, especially in relation to the care of chronic diseases such as cancer. ${ }^{5}$ The Min- istry of Health $(\mathrm{MH})$ launched by Ordinance $\mathrm{N}^{\circ} 2,439 /$ GM on December 8, 2005, its National Policy for Oncologic Care with actions related to promotion, prevention, diagnosis, treatment, rehabilitation and palliative care. ${ }^{6}$ The policy was later revised, updated and extended by Ordinance $\mathrm{N}^{\circ}$ 874/GM on May 16, 2013, which established the National Policy for Cancer Control and Prevention in the Health Care Network of Patients with Chronic Diseases under the Brazilian Unified Health System (SUS). ${ }^{7}$

This policy calls for the implementation of a line of care at all levels, in a hierarchical network, establishing the obligation of integrated care, with primary and emergency services. The latter should be provided by tertiary units, called Units for High Complexity Care in Oncology (Unacon) and Centers for High Complexity Care in 
Oncology (Cacon). These recommendations are continually updated and integrated with other policies and strategic actions for confronting chronic noncommunicable diseases $(\mathrm{CNCD})^{7}$ and with home care services (HCS). ${ }^{8}$

Oncologic patients, especially those with advanced disease, due to the natural history of their disease, anticancer therapy and/or lack of control of symptoms, may present complications or significant deterioration in their clinical condition requiring emergency care. Therefore, this action is a key part of a comprehensive care aiming to improve quality of life and relief of suffering. ${ }^{9}$

In relation to urgent and emergency services, cancer patients face difficulties and challenges, although the policy states that the Cacon must operate 24 hours a day. ${ }^{8}$

Urgent and emergency services should comply with the health care model in force in Brazil, which today often functions as access to health care. This is due to the low effectiveness of primary care and the difficulty of access to high complexity services and hospitalization. ${ }^{10}$ Nevertheless, the logic of emergency care escapes the basic principles of palliative treatment for patients at the end of life, and can lead to increased and unnecessary suffering. ${ }^{10,11}$

Considering the lack of local studies on this, our study aims to analyze the clinical and sociodemographic profile of cancer patients seen in the emergency service of a Cacon, considering the availability of palliative care (PC) and home care (HC).

\section{Method}

This is a descriptive, cross-sectional study with an analytical component carried out at the emergency room (ER) of the Instituto de Medicina Integral Prof. Fernando Figueira (Imip), a teaching and research hospital that belongs to the oncology care network of the state of Pernambuco as a Cacon center.

The study population consisted of patients with cancer treated at oncological service and attended at ER for oncologic monitored from September 2011 to December 2011 , with length of stay $>2$ hours, aged 18 years or older. The instrument used for data collection consisted of a structured questionnaire with items on sociodemographic profile, and other specific questions on reason for seeking emergency care, medical condition, diagnosis, staging, cancer treatment and monitoring in the PC outpatient clinic and HCS. We conducted a pilot study to test the instrument in early September 2011. After necessary adjustments, data collection was held from September $20^{\text {th }}$ to December $21^{\text {st }} 2011$, every day (including weekends and holidays), three times.
The database was built with double entry in the SQL Server software and Frame Work application. Frequency distribution tables, charts in Excel spreadsheet version 8.0, and statistical tests (Student's-t test for mean comparison and chi-square test) were prepared using Epi Info 3.5.3.

This project was approved by the Ethics Committee on Human Research of the Imip, no. 2426-11 and CAAE no. 0085.0.099.000-11.

\section{Results}

191 medical reviews were performed including those of 20 patients who sought the ER service two times or more. The maximum number of ER entries by a single patient was 6 , and $64.4 \%$ of the patients were female. Clinical and sociodemographic variables are shown in Table 1.

\begin{tabular}{|c|c|c|}
\hline Variables & $\mathbf{n}$ & $\%$ \\
\hline \multicolumn{3}{|l|}{ Gender } \\
\hline Female & 123 & 64.4 \\
\hline Male & 68 & 35.6 \\
\hline \multicolumn{3}{|l|}{ Age (years) } \\
\hline$\geq 60$ & 91 & 47.1 \\
\hline $40-59$ & 69 & 35.7 \\
\hline $18-39$ & 30 & 17.2 \\
\hline \multicolumn{3}{|l|}{ Origin } \\
\hline Recife & 71 & 37.2 \\
\hline GRA & 73 & 38.2 \\
\hline Others & 47 & 24.6 \\
\hline \multicolumn{3}{|l|}{ Type of treatment } \\
\hline None & 78 & 39.5 \\
\hline Chemotherapy & 60 & 30.3 \\
\hline Radiotherapy & 19 & 9.6 \\
\hline Hormone replacement & 16 & 8.1 \\
\hline Chemo and radiotherapy & 11 & 5.5 \\
\hline Surgery & 3 & 1.5 \\
\hline Others & 11 & 5.5 \\
\hline
\end{tabular}

\begin{tabular}{lll}
\hline Progression & & \\
\hline Hospital discharge & 86 & 45.0 \\
\hline Admission & 97 & 50.8 \\
\hline Transfer & 4 & 2.1 \\
\hline Death & 4 & 2.1 \\
\hline
\end{tabular}

GRA: great Recife area.

Most patients came from Recife and greater area (75.4\%). They were aged between 19 and 91 years, mean 57 years, and $47.6 \%$ were older than 60 . Among the identified clin- 
ical conditions, only $4.2 \%$ were characterized as oncologic emergencies, and $19.9 \%$ as infection. The most frequent symptom was pain (46.6\%) and there was no statistically significant difference in any particular subgroup in that respect. As for tumor topography, cervical (18.3\%), breast (13.6\%) and prostate $(10.5 \%)$ cancers were predominant. Advanced disease characterized as stages III and IV represented $70.7 \%$ of patients, with $47.1 \%$ at stage IV. In $14.7 \%$ of the reviews, patients were still at staging phase.

Regarding oncological therapeutic modalities being offered at the time of admission (Table 2), 39.4\% had no specific treatment, $30.3 \%$ were undergoing chemotherapy, 9.6\% were undergoing radiotherapy, and $5.6 \%$ chemotherapy combined with radiotherapy.

TABLE 2 Clinical characteristics of cancer patients seen in
the emergency service of the Imip, and treated by home
care and/or palliative care. Recife, 2011.

${ }^{*}$ Gastrointestinal tract; HCS: home care services; PC: palliative care.
$4.2 \%$ of patients were being monitored in the PC outpatient clinic and $2.1 \%$ in HCS. No statistically significant differences were observed between the groups of patients in PC and $\mathrm{HC}$ in relation to complaints of pain (Table 3).

\begin{tabular}{|c|c|c|c|c|c|}
\hline $\begin{array}{l}\text { Clinical } \\
\text { status }\end{array}$ & $\begin{array}{l}\text { Hospital } \\
\text { discharge } \\
\text { n (\%) }\end{array}$ & $\begin{array}{l}\text { Admission } \\
\text { n (\%) }\end{array}$ & $\begin{array}{l}\text { Death } \\
n\end{array}$ & $\begin{array}{l}\text { Transfer } \\
\text { n }\end{array}$ & $\begin{array}{l}\text { Total } \\
\text { n (\%) }\end{array}$ \\
\hline Infection & $8(9.4)$ & $28(28.9)$ & 1 & - & $\begin{array}{l}37 \\
(19.4)\end{array}$ \\
\hline $\begin{array}{l}\text { Disease } \\
\text { progression }\end{array}$ & $2(2.4)$ & $27(27.8)$ & - & - & $\begin{array}{l}29 \\
(15.2)\end{array}$ \\
\hline $\begin{array}{l}\text { Treatment } \\
\text { toxicity }\end{array}$ & $9(10.6)$ & $6(6.2)$ & - & - & $\begin{array}{l}15 \\
(7.9)\end{array}$ \\
\hline $\begin{array}{l}\text { Oncologic } \\
\text { emergency }\end{array}$ & $1(1.2)$ & $6(6.2)$ & - & 1 & $8(4.2)$ \\
\hline Unknown & $47(55.3)$ & $8(8.2)$ & 1 & 2 & $\begin{array}{l}58 \\
(30.4)\end{array}$ \\
\hline Other & $19(22.1)$ & $22(22.7)$ & 2 & 1 & $\begin{array}{l}44 \\
(23.0)\end{array}$ \\
\hline Total & 86 & 97 & 4 & 4 & 191 \\
\hline
\end{tabular}

\section{Discussion}

This study used the emergency care as a proxy for the quality of care provided to cancer patients and the effectiveness of pain control programs, under PC and HCS.

Emergency care is an important part of the comprehensive care of cancer patients. ${ }^{7}$ However, there were few cases characterized as oncologic emergencies reviewed at the ER/Imip, unlike other countries. ${ }^{11-15}$ In this study, most of the demands were medical situations that could be assessed and classified according to risk, and assisted by a general practitioner in their places of residence; many were related to deficient care network.

The reorganization of the hierarchical and regionalized network would prevent one in five patients to be displaced from rural areas in the state for case review in a reference hospital, as noted here. The trip can aggravate the clinical status due to transport difficulties, increase the suffering of the patient and family, and generate family financial expenditure and system overload in the higher complexity service.

The high prevalence of breast and cervical cancer in patients who sought emergency care at the Imip (about $1 / 3$ of all cancers) may portray late diagnosis, poor access 
to diagnostic screening with cytology, low quality examination and also difficult access to specialized services, which is mostly supported by the prevalence of diagnosis being made with advanced disease (stage III and IV).

It is estimated that 30 to $90 \%$ of cancer patients are affected by moderate to severe pain in the course of their disease and that $80 \%$ of patients in the terminal phase are affected..$^{9,11,13-15}$ In this study, the main complaint in the emergency room was pain, similar to that reported in a 2007 systematic review. ${ }^{16}$ However, even with the recommendation of the World Health Organization (WHO) ${ }^{17}$ and the Brazilian $\mathrm{MH}^{7}$ as well as a high probability of success in pain control, this symptom is still neglected worldwide. ${ }^{18}$

Knowledge and skills development for adequate pain management should be a priority for health professionals. Also, public health managers should be sensitized to this possibility in order to provide the units with standard resources for effective control of pain in $95 \%$ of cancer patients, ${ }^{19,20-22}$ and thus promote patient welliness. ${ }^{7,12}$

There are several hypotheses for the inadequate control of pain: from difficulty of the medical staff to properly measure the complaint, to the arrogance-ignorance paradox in the medical profession; ${ }^{22}$ in addition, there is also insufficient medical knowledge about opioids and pain treatment, and lack of pain medication or difficulty to obtain opioids, combined with the legal difficulties to prescribe such drugs. ${ }^{12,18,20,21}$

A result that draws attention is that approximately half of patients do not receive any specific cancer therapy. This suggests that the emergency service allows the start of treatment for new situations resulting from the disease, or not directly related to cancer. The situation finds no support in the Policy, ${ }^{7}$ which broadens access when it expands the assistance to all levels of complexity, and gives the idea that the patients already have disease at such an advanced stage that they would no longer benefit from these therapies.

Several cultural and social barriers, and others associated with the training of human resources, restructuring of logic supply of care and integration of knowledge and practices that need to be overcome, ${ }^{18,23,24}$ are reported in the implementation of PC services in Brazil and worldwide.

The $\mathrm{WHO}^{21}$ and the Brazilian $\mathrm{MH}^{7}$ propose the offering of $\mathrm{PC}$ services as soon as possible whenever diseases considered severe, progressive, incurable, threatening the continuity of life, are diagnosed. These services can be provided even at a primary level. At first, such care does not exclude specific antineoplastic therapies. ${ }^{24,25}$ Howev- er, we see that the referral of patients to PC services has occurred repeatedly in the late stages of the disease, representing a major barrier to access in many parts of the world. ${ }^{26,27}$

The finding that few cancer patients treated at the ER were in PC or HC promoted a discussion among professionals of the institution in order to create expansion strategies. This is because the evidence shows that the implementation of these instances of care improves symptom control and the quality of life of cancer patients, reducing the demand for emergency care..$^{24,28,29}$

Cases that should be reviewed in other levels of care (outpatient, home, basic unit), hinder patient monitoring when treated in emergency services. This is due both to the absence of records produced in emergency settings, and the lack of an integrated system with outpatient information. Service levels should operate together, under the same regulation, with reference and counter-reference that provides monitoring sites before and after the emergency care. ${ }^{12,17}$

\section{Conclusion}

The results of this study proved challenging for service providers and for policymakers. The main types of cancer identified in the emergency could be prevented, diagnosed early, treated and cured. And even in cases with advanced stages, the pain could have been reduced and the family assisted in order to cope with the disease.

However, incipient levels of PC and HCS coverage were found, indicating that these services need to be expanded and integrated into early cancer therapy aimed at relieving the suffering of both the patients and their families. Palliative care should be part of the skills required not only from oncologists, but from all health professionals who work in emergency services.

\section{Resumo}

Pacientes oncológicos, serviço de urgência e oferta de cuidados paliativos

Objetivo: descrever o perfil clínico e sociodemográfico de pacientes oncológicos atendidos na emergência de um Centro de Alta Complexidade em Oncologia, observando a cobertura dos cuidados paliativos e assistência domiciliar.

Método: estudo de corte transversal com adultos oncológicos atendidos na emergência (setembro a dezembro de 2011) e tempo de permanência superior a 2 horas. Usaram-se teste t-Student de comparação de médias e qui-quadrado. 
Resultados: participaram 191 pacientes, 47,6\% idosos, $64,4 \%$ mulheres e $75,4 \%$ procedentes de Recife e região metropolitana. Dor $(46,6 \%)$ foi o sintoma prevalente à admissão. Os pacientes sob cuidados paliativos eram 4,2\% e sob atenção domiciliar, $2,1 \%$. Os cânceres mais frequentes foram colo uterino (18,3\%), mama (13,6\%) e próstata (10,5\%), sendo 70,7\% em estadios avançados (IV, 47,1\%) e $40 \%$ sem terapia oncológica.

Conclusão: a procura da emergência por causa de dor deveu-se, provavelmente, à baixa cobertura de cuidados paliativos e atenção domiciliar, os quais precisam ser associados precocemente à terapia oncológica para minimização do sofrimento dos pacientes/familiares e integrar as competências de oncologistas e profissionais de emergências.

Palavras-chave: neoplasias, cuidados paliativos, serviços de assistência domiciliar, serviços médicos de emergência.

\section{References}

1. World Health Organization (WHO). International Agency for Research on Cancer. Globocan 2012: Estimated Cancer incidence, mortality and prevalence in worldwide in 2012. [cited 2014 Jan 09]. Available from: http://globocan. iarc.fr/Pages/summary_table_site_prev_sel.aspx.

2. Ripsa. Rede Interagencial de Saúde. Indicadores e Dados Básicos do Brasil (IDB. 2012) Mortalidade Proporcional por Grupo de Causas. [cited 2014 Jan 07] Available from: http://tabnet.datasus.gov.br/cgi/tabcgi.exe?idb2012/c04.def.

3. Jemal A, Bray F, Center MM, Ferlay J, Ward E, Forman D. Global cancer statistics. CA Cancer J Clin. 2011; 61:69-90. Available from: http:// onlinelibrary.wiley.com/doi/10.3322/caac.20107/full

4. Schmidt MI, Duncan BB, Azevedo e Silva G, Menezes AM, Monteiro CA Barreto SM, et al. Chronic non-communicable diseases in Brazil: burden and current challenges. Lancet. 2011;377(9781):1949-61.

5. Brasil, Ministério da Saúde. Secretaria de Vigilância em Saúde. Departamento de Análise de Situação de Saúde. Plano de ações estratégicas para o enfrentamento das doenças crônicas não transmissíveis (DCNT) no Brasil. 2011-2022. Brasília: Ministério da Saúde, 2011. 148p.: il. - (Série B. Textos Básicos de Saúde). 27-32. [cited 2013 Sep 20]. Available from: http://189.28.128.100/dab/docs/geral/plano_acao_dcnt_julho.pdf.

6. Brasil, Ministério da Saúde. Portaria n. 2.439/GM de 08 de dezembro de 2005. Institui a política nacional de atenção oncológica: promoção, prevenção diagnóstico, tratamento, reabilitação e cuidados paliativos. [cited 2013 Dec 19]. Available from: http://bvsms.saude.gov.br/bvs/saudelegis/gm./2005/ prt2439_08_12_2005.html.

7. Brasil. Ministério da Saúde. Portaria n. 874, de 16 de maio de 2013. Institui a política nacional para a prevenção e controle do câncer na rede de atenção à saúde das pessoas com doenças crônicas no âmbito do Sistema Único de Saúde (SUS). Brasília, 2013. [cited 2013 Dec 19]. Available from: http:// bvsms.saude.gov.br/bvs/saudelegis/gm/2013/prt0874_16_05_2013.html.

8. Brasil. Ministério da Saúde. Portaria n. 2.029, de 24 de agosto de 2011. Institui a atenção domiciliar no âmbito do Sistema Único de Saúde (SUS). [cited
2012 Sep 13]. Available from: http://bvsms.saude.gov.br/bvs/saudelegis/ gm/2011/prt2029_24_08_2011.html.

9. Barbera L, Taylor C, Dudgeon D. Why do patients with cancer visit the emergency department near the end of life? CMAJ. 2010; 182(6):563-8.

10. O’Dwyer GO, Oliveira SP, Seta MH. Avaliação dos serviços hospitalares de emergência do programa QualiSUS. Ciênc. saúde coletiva. 2009; 14(5):1881-90.

11. Royal College of Physicians and Royal College of Radiologists. Cancer patients in crisis: responding to urgent needs. Report of a working party. London: RCP 2012. [cited 2013 Dec 12]. Available from: http://www.rcplondon.ac.uk/sites/ default/files/documents/cancer-patients-in-crisis-report.pdf.

12. Quest TE, Asplin BR, Cairns CB, Hwang U, Pines JM. Research priorities for palliative and end-of-life care in the emergency setting. Acad Emerg Med. 2011; 18(6):e70-6.

13. Behl D, Hendrickson AW, Moynihan TJ. Oncologic emergencies. Crit Care Clin. 2010; 26(1):181-205

14. Ahn S, Lee YS, Lim KS, Lee JL. Emergency department cancer unit and management of oncologic emergencies: experience in Asian Medical Center. Support Care Cancer. 2012; 20(9):2205-10.

15. Yates M, Barrett A. Oncological emergency admissions to the Norfolk and Norwich University Hospital: an audit of current arrangements and patient satisfaction. Clin Oncol (R Coll Radiol). 2009; 21(3):226-33.

16. Van den Beuken-van Everdingen MHJ, Rijke JM, Kessels AG, Schouten HC, Van Kleef M, Patijn J. Prevalence of pain in patients with cancer: A systematic review of the past 40 years. Ann Oncol. 2007; 18(9):1437-49.

17. World Health Organization. WHO global action plan for the prevention and control of noncommunicable diseases 2013-2020.

18. Breuer B, Fleishman SB, Cruciani RA, Portenoy RK. Medical oncologists' attitudes and practice in cancer pain management: a national survey. J Clin Oncol. 2011; 29(36):4769-75.

19. Grudzen CR, Richardson LD, Morrison M, Cho E, Morrison RS. Palliative care needs of seriously ill, older adults presenting to the emergency department. Acad Emerg Med. 2010; 17(11):1253-7.

20. Wiese C, Bartels U, Ruppert D, Quintel M, Graf BM, Hanekop GG. Quality of out-of-hospital palliative emergency care depends on the expertise of the emergency medical team - a prospective multi-centre analysis. Support Care Cancer. 2009; 17(12):1499-506.

21. World Health Organization WHO. Palliative care. Cancer control: knowledge into action: WHO guide for effective programs; module 5. Genève: 2007. 51p.

22. Lamas D, Rosenbaum L. Painful inequities - Palliative care in developing countries. N Engl J Med. 2012; 366(3):199-201.

23. Bruera E, Hui D. Integrating supportive and palliative care in the trajectory of cancer: establishing goals and models of care. J Clin Oncol. 2010 28(25):4013-7.

24. Smith TJ, Temin S, Alesi ER, Abernethy AP, Balboni TA, Basch EM, et al. American Society of Clinical Oncology provisional clinical opinion: the integration of palliative care into standard oncology care. J Clin Oncol. 2012; 30(8):880-7.

25. Ferris EB, Bruera E, Cherny N, Cummings C, Currow D, Dudgeon D, et al. Palliative cancer care a decade later: accomplishments, the need, next steps - from the American Society of Clinical Oncology. J Clin Oncol. 2009; 27(18):3052-8

26. Crawley LM, Marshall PA, Lo B, Koenig BA; End-of-Life Care Consensus Panel. Strategies for culturally effective end of life care. Ann Intern Med. 2002; 136(9):673-9.

27. Quill TE, Abernethy AP. Generalist plus specialist palliative care-creating a more sustainable model. N Engl J Med. 2013; 368(13):1173-5.

28. Carvalho RT, Parsons HAF (orgs.). Academia Nacional de Cuidados Paliativos (ANCP). Manual de Cuidados Paliativos ANCP. 2.ed. [cited 2013 Jul 13]. Available from: http://www.paliativo.org.br/ancp.php? $\mathrm{p}=$ oqueecuidados.

29. Academia Nacional de Cuidados Paliativos (ANCP). O que são Cuidados Paliativos? 2011 [cited 2012 Jul 13]. Available from: http://www.paliativo. org.br/ancp.php? $\mathrm{p}=$ oqueecuidados. 